Selcuk Journal of Agriculture and Food Sciences

http://sjafs.selcuk.edu.tr/sjafs/index

Research Article
SJAFS

(2021) 35 (3), 259-264

e-ISSN: $2458-8377$

DOI:10.15316/SJAFS.2021.255

\title{
Determination of Natural Flow Rates of Some Chickpea Varieties on Different Surfaces and Surface Angles
}

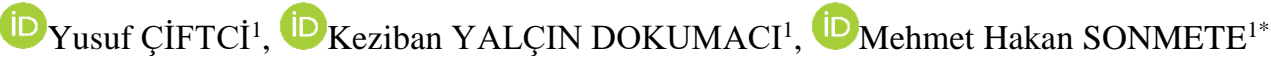

${ }^{1}$ Selçuk University, Faculty of Agriculture, Department of Agricultural Machinery and Technologies Engineering, Konya, Turkey

ARTICLE INFO

Article history:

Received date: 26.10 .2021

Accepted date: 15.11 .2021

\section{Keywords: \\ Chickpea \\ Natural flow rate \\ Physical properties \\ Surface angle \\ Surface material}

\begin{abstract}
In this study, some physical properties of Gökçe chickpea (registered variety) and Spanish chickpea (local population) variety cultivated in Konya Province were determined. Flow rates of chickpea varieties were detected at four different conveyor channel angles $\left(24^{\circ}, 28^{\circ}, 32^{\circ}\right.$ and $\left.36^{\circ}\right)$ and on three different surfaces (galvanized sheet, painted sheet and steel sheet surfaces). Length, width, thickness, geometric mean diameter, sphericity, repose angle, thousand grain weight, bulk density values of Gökçe chickpeas at $8.90 \%$ moisture level are $10.09 \mathrm{~mm}, 7.34 \mathrm{~mm}, 7.74 \mathrm{~mm}$ and $8.30 \mathrm{~mm}, 0.82,18.04^{\circ}, 364.6 \mathrm{~g}$ and $746.82 \mathrm{~kg} \mathrm{~m}^{-3}$ and for Spanish variety at $10.40 \%$ moisture level are $12.16 \mathrm{~mm}$, $8.22 \mathrm{~mm}, 9.01 \mathrm{~mm}, 9.65 \mathrm{~mm}, 0.79,16.01^{\circ}, 481.96 \mathrm{~g}, 690.21 \mathrm{~kg} \mathrm{~m}^{-3}$ were determined respectively. These varieties, the static friction coefficient values on galvanized sheet, painted sheet and steel sheet surfaces were found to be 0.335 and $0.351,0.401$ and $0.445,0.388$ and 0.435 , respectively. Flow rates increased as the channel conveyor angle increased on galvanized sheet, painted sheet and steel sheet surfaces. The increase rates for Gökçe and Spanish chickpeas on these surfaces were $207 \%$ and $189 \%, 630 \%$ and $522 \%, 291 \%$ and $202 \%$, respectively. When the surface averages are taken into account, average flow rates of $1.69 \mathrm{~kg} \mathrm{~s}^{-1}$ on the galvanized sheet surface, $1.24 \mathrm{~kg} \mathrm{~s}^{-1}$ on the painted sheet surface and $1.54 \mathrm{~kg} \mathrm{~s}^{-1}$ on the steel sheet surface were obtained and found to be statistically significant. The difference between the surfaces is due to the roughness values of the surfaces. The lowest average roughness value was found on the galvanized sheet surface $(1.13 \mu \mathrm{m})$, and the highest on the painted surface $(2.06 \mu \mathrm{m})$. According to the triple interaction results, the highest flow rate value was obtained on the galvanized sheet surface and the conveyor angle of $36^{\circ}$ in both chickpea varieties, and the lowest flow values were obtained at the conveyor angle of $24^{\circ}$ on the painted sheet surface.
\end{abstract}

\section{Introduction}

Chickpea (Cicer arietinum L.) is a plant cultivated and produced among the edible legumes in our country. It is generally produced in arid and semi-arid regions. In addition to this, it is the most resistant to salt among the edible legumes. With this aspect, chickpea is one of the legumes that can be preferred in crop rotation systems to be applied in places where salinity is a problem.

Chickpea is the most resistant to heat and drought among legumes. It can easily grow in soils with low organic matter, and it has an important place in reducing fallow areas by entering crop rotation in our arid regions where winter grain-fallow rotation is applied.

*Corresponding author email: sonmete@selcuk.edu.tr
Chickpeas are an important source of protein. Chickpea, which is also rich in carbohydrates, vitamins and minerals, has a versatile consumption area as edible, snack and animal feed. Chickpea seeds contain $29 \%$ protein, $3 \%$ fiber, $59 \%$ carbonhydrate, $5 \%$ oil and $4 \%$ ash. Although chickpea is deficient in the sulfurcontaining amino acids cystine and methionine, it is a rich source of arginine and lysine (Iqbal et al. 2006).

Edible legumes have positive effects on soil fertility as well as their high protein content. They are taproot and form a symbiosis with Rhizobium spp. bacteria and bind the free nitrogen of the air to the soil $(6.4-21.6 \mathrm{~kg}$ $\mathrm{da}^{-1}$ pure nitrogen). The fact that the $\mathrm{C} / \mathrm{N}$ coefficient of plant residues remaining after the harvest of edible legumes is quite low increases the importance of these plants (Karakullukçu and Adak 2008).

The cultivation area, yield and production values of chickpea in dry agriculture in Turkey and Konya are given in Table 1. When the data of 2020 are examined, it is seen that chickpea is cultivated on an area of 5115 
607 da in Turkey and there is a total production of 630 000 tonnes. Chickpea cultivation area in Konya Region constitutes $7.17 \%$ of the cultivation area in our country

Table 1

Cultivation area, yield and production values of dried chickpeas in Turkey and Konya (TÜİK 2021)

\begin{tabular}{ccccccc}
\hline & \multicolumn{2}{c}{ Cultivated area $(\mathrm{da})$} & \multicolumn{2}{c}{ Yield $\left(\mathrm{kg} \mathrm{da}^{-1}\right)$} & \multicolumn{2}{c}{ Production (tonnes) } \\
\cline { 2 - 6 } Years & Turkey & Konya & Turkey & Konya & Turkey & Konya \\
\hline 2016 & 3595289 & 213707 & 129 & 151 & 455000 & 32139 \\
2017 & 3953099 & 246491 & 120 & 143 & 470000 & 34586 \\
2018 & 5144159 & 351518 & 123 & 139 & 630000 & 48845 \\
2019 & 5205951 & 336196 & 122 & 139 & 630000 & 46858 \\
2020 & 5115607 & 366721 & 123 & 137 & 630000 & 50112 \\
\hline
\end{tabular}
on markets. These varieties are also used in breeding studies to develop new cultivars. Production of local cultivars does not be compatible organic farming principles as these are grown by using conventional farming systems.

Physico-mechanical properties of chickpea play a significant role in designment of storage structures and selection of storage material (Kashaninejad et al. 2006).

Physical properties and the orifice shape of the material influence the flow rate of the material. While the unit weight has an impact on compressibility and internal friction angle of grain, the shape of the grain and distribution are important in terms of flowability (Fitzpatrick et al. 2004).

In most studies, it has focused on the flow rate of material, the relationship between material properties and flow rate and regularity of flow in different orifices. For example, it has been investigated by Mohsenin (1986) that factors affecting grain flow such as silo geometry, orifice height diameter ratio and shape. And also, the equation describing the grain flow rate has been formed.

Turgut et al. (1994 and 1995) determined the flow smoothness of triple super phosphate and diammonium phosphate fertilizer in various orifices. They found that the flow smoothness of triple super phosphate fertilizer was significantly influenced by the shape and openness of the orifice. The most irregular output occurred in rectangular orifices and in the small voids. They concluded that the flow rate of diammonium phosphate fertilizers, in terms of orifice shape and the base angle was affected, and the height of the storage material has no effect on the flow rate.

Değirmencioğlu et al. (1998) developed a model for the flow of fertilizers and seeds through orifices of different sizes and shapes under the influence of gravity, by using dimensional analysis. Dimensionless terms were created in accordance with the Buckingham Pitheorem and the estimation model was developed with multiple regression analysis and the estimation coefficient of the model was found to be $92.3 \%$. The most important variable in the model was the angle of the orifice with the horizontal and it was determined that it could explain $61.5 \%$ of the variation in the obtained data.
Nowadays, more local varieties are grown and put and meets $7.95 \%$ of its production, and its yield value is approximately $111.4 \%$ higher than the average of Turkey.
Değirmencioğlu et al. (1999) measured the flow rate of granular fertilizers (urea, TSP and ammonium nitrate) and wheat and corn seeds from circular and sharp-edged (non-circular) orifices in laboratory conditions on a mass basis. They developed a new prediction model to estimate the flow rate from larger holes using stepwise regression analysis and determined the prediction coefficient of the model to be $94.7 \%$.

Elaskar et al. (2001) obtained velocity profiles by recording images during the flow of sorghum through rough and smooth channels. They determined that the velocity increased by $113 \%$ when the surface of sliding slope angles increased from $18^{\circ}$ to $38^{\circ}$. In addition, they reported that the maximum velocity occurred at an inclination angle of $37^{\circ}$, and the flow rate increased by $377 \%$ when the inclination angle increased from $30^{\circ}$ to $37^{\circ}$.

Akar (2003) stated that natural flow rates of okra cultivars such as Amasya and Sultani depending on channel shape, flow angle and moisture content. In the study, it was determined that the increase in moisture content caused a decrease in the flow rate for both varieties, and the natural flow could not be achieved at a slope angle of $30^{\circ}$ depending on the moisture content. It has also been reported that the highest natural flow was obtained in the experiment performed in the galvanized steel channel.

Karacabey et al. (2009) a model developed for the flow of fertilizers and seeds under the effect of gravity through orifices with different shapes and crosssections was analyzed with the genetic algorithm approach, which is one of the solution methods, and they determined the measures that provide the highest material flow of trapezoidal orifices. As a result of the optimization, different sizes were determined in trapezoidal orifices with the same area, and 42-1280 $\mathrm{kg} \mathrm{h}^{-1}$ increases were achieved in the flow of seed and fertilizer material for orifices with a cross-sectional area of $2000 \mathrm{~mm}^{2}, 7800 \mathrm{~mm}^{2}, 17600 \mathrm{~mm}^{2}$ and $31400 \mathrm{~mm}^{2}$ used in modeling.

Soliman et al. (2017) Jasmine (long) and Sakha (short) three different varieties of rice seeds in their study examined the flow properties depending on the variables in 3 groups. In the first group, three different diameter openings $(6,8$ and $10 \mathrm{~cm})$, in the second group three different openings and 4 different angles from the elbow $\left(15^{\circ}, 30^{\circ}, 45^{\circ}\right.$ and $\left.60^{\circ}\right)$ and in the last 
group three different holes and five different slopes $\left(0^{\circ}\right.$, $15^{\circ}, 30^{\circ}, 45^{\circ}$ and $\left.60^{\circ}\right)$ and three pipe lengths $(0.5,1$ and $1.5 \mathrm{~m}$ ) determined the natural flow properties of rice grains. The highest fluidity factor was obtained as 4.193 in White Sakha 103 variety with a surface friction coefficient of $0.30 \mu \mathrm{s}$, a spherical value of 0.540 , and a thousand-grain weight of $21.80 \mathrm{~g}$.

Arıkaymak and Hacıseferoğulları (2021) reported that the flow was seen on all surfaces and at all channel angles in the Horoz dry bean variety. Furthermore, in Sarkıı and Basara varieties, flow occurred on the painted sheet surface at $24^{\circ}$ channel angle, while in Sarkk1z variety, there was no flow on the flat sheet surface at $24^{\circ}$ channel angle. Among the cultivars, the highest average flow rate $\left(1.61 \mathrm{~kg} \mathrm{~s}^{-1}\right)$ occured in Horoz dry bean cultivar and such a flow rate was mostly achieved by surface profile and grain physical characteristics. The greatest flow rate was obtained from 360 conveyor channel angle $\left(2.01 \mathrm{~kg} \mathrm{~s}^{-1}\right)$. Surface roughness affected flow rates and the greatest flow rate on galvanized sheet surface with the lowest surface roughness was measured as $1.66 \mathrm{~kg} \mathrm{~s}^{-1}$. In line with these findings, it was revealed that the physical properties of the cultivars, the channel roughness and angle affected the flow rates.

In the present study, some physical properties of two chickpea varieties, which are Gökçe (registered variety) and Spanish (local population) chickpea varieties cultivated in Konya Province, were determined and natural flow rates of these chickpea varieties on different flow surfaces and angles were detected.

\section{Materials and Methods}

In the trials, Gökçe and Spanish chickpea varieties, all of which are cultivated in the Konya region, were used. The thousand grain weight of crops was measured on electronic balance (accuracy of $\pm 0.001 \mathrm{~g}$ ). In order to measure the thousand grain weight, 100 grains of each variety were randomly selected as three replications. Dimensional properties of grains were measured by using a micrometer with an accuracy of $0.01 \mathrm{~mm}$. Sphericity $(\Phi)$ and geometric mean diameter $\left(D_{g}\right)$ values were calculated using the following equations (Mohsenin, 1986).

$\mathrm{D}_{\mathrm{g}}=(\mathrm{LWT})^{1 / 3}$

$\Phi=\mathrm{D}_{\mathrm{g}} / \mathrm{L}$

Where,

$\mathrm{D}_{\mathrm{g}} \quad$ : Geometric mean diameter (mm)

$\Phi \quad$ : Sphericity (-)

L : Length of grain (mm)

W : Width of grain $(\mathrm{mm})$

$\mathrm{T}$ : Thickness of grain (mm)

The materials were slowly and freely poured on a flat surface to determine the angle of repose. The spilled materials formed a cone on the surface. The angles of repose were determined by calculating the tangent value (internal friction coefficient) of the horizontal angle of this cone.

Each crop was poured into a one-liter glass vessel with a velocity of 12 seconds per liter. After shedding the excess crop up to the vessel, the remaining crop was weighed. The bulk density was determined by dividing the weight of grain by the volume of the vessel.

The coefficient of static friction was measured on painted sheet, steel sheet and galvanized sheet surfaces. In this measurement, one end of the friction surface was connected to the endless screw and the chickpea grain was placed on the surface and gradually raised with the screw. During the sliding movement of the chickpea grain on the surface, the horizontal and vertical height values were read from the ruler and recorded. Afterwards, the static friction coefficient was calculated by using the tangent value of the angle found. Baryeh (2001) and Gezer et al. (2003) have used similar methods in their researches.

The experimental test unit used in this research was designed specifically and the flow rate values were determined using it. This test unit consists of a cylindrical feeding hopper cone-shaped with a capacity of five liters, it has a discharge slide valve that can be opened easily at the bottom of the hopper and a conveyor channel. The channel conveyors which have three different surfaces such as steel sheet, galvanized steel sheet and painted steel sheet and have a $0.5 \mathrm{~m}$ length were used in the experiment. Inside radius and overall inside depth of the channel conveyor are $53 \mathrm{~mm}$ and $78 \mathrm{~mm}$, respectively. A special structure is made to support the channel and hopper. A schematic view of this experimental test unit was shown in Figure 1.

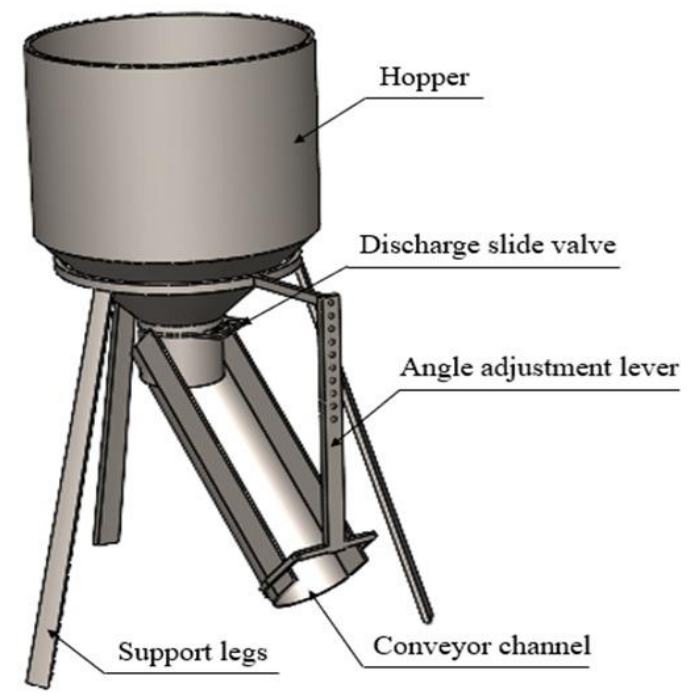

Figure 1

A schematic view of natural flow test unit

During the trials, after a cone-shaped hopper was filled with material, the discharge slide valve cover at the bottom of the storage was opened, and the digital chronometer was operated simultaneously. When all material passed to the channel conveyor, the chronometer was stopped and the elapsed time was determined. 
These values were divided by the mass of the material, and the natural flow rates were determined as three replications.

There are three values to define surface roughness: $\mathrm{R}_{\mathrm{z}}$ (the measured roughness value), $\mathrm{R}_{\mathrm{a}}$ (the mathematical average roughness value), and $R_{\max }$ (the biggest surface roughness). $R_{z}, R_{a}$ and $R_{\max }$ values were measured by using profilmeter device (measurement range of 0-150 $\mu \mathrm{m}$, Marsurf brand) repeated three times (Figure 2).

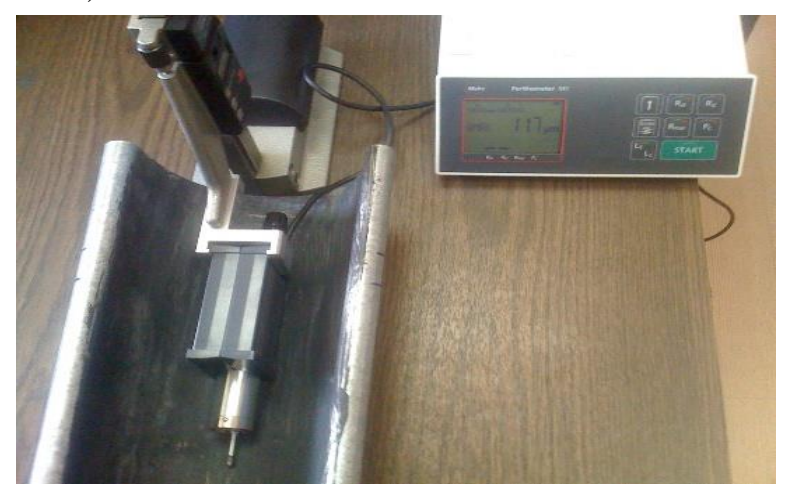

Figure 2

Profilmeter device measuring roughness on painted sheet surface

In the statistical analysis of the data obtained, variance analysis was applied using the MINITAB 16 program, and LSD analysis was performed by using the MSTAT-C package program to determine the different groups.

\section{Results and Discussion}

The mathematical mean roughness values $\left(\mathrm{R}_{\mathrm{a}}\right)$ of the galvanized sheet surface, the steel sheet surface, and the painted sheet surface were found to be 1.13 , 1.20 and 2.06 respectively. Some physical properties of dry chickpea cultivars used in the study are given in Table 2. The length, width, thickness, geometric mean diameter and thousand-grain mass values of the grain were found to highest in the Spanish chickpea cultivar as $12.06 \mathrm{~mm}, 8.22 \mathrm{~mm}, 9.01 \mathrm{~mm}, 9.65 \mathrm{~mm}$ and 481.96 $\mathrm{g}$, respectively.

\section{Table 2}

Some physical properties of chickpeas

\begin{tabular}{lcc}
\hline Properties & Gökçe chickpea & Spanish chickpea \\
\hline Moisture (\%) & 8.90 & 10.40 \\
Length (mm) & $10.09 \pm 0.07$ & $12.16 \pm 0.09$ \\
Width $(\mathrm{mm}$ & $7.34 \pm 0.07$ & $8.22 \pm 0.07$ \\
Thickness (mm) & $7.74 \pm 0.06$ & $9.01 \pm 0.08$ \\
Geometric mean diameter (mm) & $8.30 \pm 0.056$ & $9.65 \pm 0.069$ \\
Sphericity (-) & $0.82 \pm 0.005$ & $0.79 \pm 0.004$ \\
Angle of repose $\left(^{\circ}\right.$ ) & $18.04 \pm 1.06$ & $16.01 \pm 0.78$ \\
Thousand grain weight $(\mathrm{g})$ & $364.6 \pm 0.73$ & $481.96 \pm 6.36$ \\
Bulk density $\left(\mathrm{kg} \mathrm{m}^{-3}\right)$ & $746.82 \pm 5.83$ & $690.21 \pm 16.29$ \\
\hline Coefficient of static friction & & $0.351 \pm 0.010$ \\
\hline Galvanized sheet surface & $0.335 \pm 0.014$ & $0.445 \pm 0.015$ \\
Painted sheet surface & $0.401 \pm 0.015$ & $0.435 \pm 0.012$ \\
Steel sheet surface & $0.388 \pm 0.010$ & \\
\hline
\end{tabular}

In the same chickpea cultivar, sphericity, natural repose angle and bulk density values were determined to be the lowest at $0.82,18.04^{\circ}$ and $746.82 \mathrm{~kg} \mathrm{~m}^{-3}$. The coefficient of static friction values for the galvanized sheet, the painted sheet, and the steel sheet surfaces varied from 0.335 to 0.445 . The lowest values of coefficient of static friction were obtained from the galvanized sheet surface, and the highest values of coefficient of static friction were obtained from the painted sheet surface.

When the results of the research are compared with the other studies carried out with chickpea varieties in Turkey, it is seen that the sphericity value of the Koçbaşı variety is higher $(87.58 \%)$ at the moisture value of $5.2 \%$ (d.b), and the length $(9.34 \mathrm{~mm})$ and width $(7.72 \mathrm{~mm})$ value is lower than Gökçe and Spanish (Konak et al. 2002).

Length, width, thickness, thousand-grain weight of Black Kabuli chickpea seeds were reported $6.85 \mathrm{~mm}$, $5.08 \mathrm{~mm}, 4.72 \mathrm{~mm}$ and $100.18 \mathrm{~g}$ respectively, static friction coefficient values were also reported 0.172 for stainless steel and 0.282 galvanized iron surfaces. These values were lower than Spanish and Gökçe chickpea varieties (Gürhan et al. 2009)

It was determined that the sphericity and bulk density values of Ilc-482 and Diyar-95 chickpea cultivars were higher as $86.2 \%$ to $795 \mathrm{~kg} \mathrm{~m}^{-3}$ and $89.8 \%$ to 792 $\mathrm{kg} \mathrm{m}^{-3}$, respectively (Gürsoy and Güzel 2010).

The natural flow rate values for different surfaces and channel conveyor angles were shown in Table 3. By increasing the channel conveyor angles, the natural flow rate values increased on all surfaces. It is seen that the flow rate is low in both chickpea varieties at a channel angle of $24^{\circ}$ on the painted sheet surface. The reason for this is that the static friction coefficient value on the painted sheet surface is more. The less of the natural repose angle of the Spanish variety chickpea was effective in obtaining higher flow rates at all surface and transmission angles. The angle of repose of the granular material is important in the design of transmission machines. 
It is shown that the different channel angles of different dry chickpea cultivars and the natural flow rates obtained on the transmission surface in Table 3. According to the variance analysis results applied to these values, a statistically significant relationship was determined between the triple $(\mathrm{p}<0.10)$ and all other parameters and their interactions $(\mathrm{p}<0.01)$.

When the averages of chickpea cultivars were examined, the highest flow rate was $1.55 \mathrm{~kg} \mathrm{~s}^{-1}$ in Spanish chickpea cultivar and $1.43 \mathrm{~kg} \mathrm{~s}^{-1}$ in Gökçe chickpea cultivar, and the difference between them was statistically significant $(\mathrm{F}=88.11)$. Low repose angle and grain surface profile were effective in obtaining high flow rate in Spanish chickpea variety.
Flow rates increased as the channel conveyor angle increased on galvanized sheet, painted and sheet metal surfaces. The increase rates for Gökçe and Spanish chickpeas on these surfaces were $207 \%$ and $189 \%$, $630 \%$ and $522 \%, 291 \%$ and $202 \%$, respectively. Considering the surface averages, mean of flow rates of $1.69 \mathrm{~kg} \mathrm{~s}^{-1}$ on the galvanized sheet surface, $1.24 \mathrm{~kg} \mathrm{~s}^{-1}$ on the painted sheet surface and $1.54 \mathrm{~kg} \mathrm{~s}^{-1}$ on the steel sheet surface were obtained and found to be statistically significant $(\mathrm{F}=444.43)$. The difference between the surfaces is due to the roughness values of the surfaces. The lowest mean of roughness value was found on the galvanized sheet surface $(1.13 \mu \mathrm{m})$, and the highest on the painted sheet surface $(2.06 \mu \mathrm{m})$.

Table 3

Natural flow rate values of chickpeas for different surfaces and channel conveyor angles $\left(\mathrm{kg} \mathrm{s}^{-1}\right)$

\begin{tabular}{lcccc}
\hline & \multicolumn{3}{c}{ Channel conveyor angles } \\
\cline { 2 - 5 } & $24^{\mathrm{o}}$ & $28^{\circ}$ & $32^{\circ}$ & $36^{\circ}$ \\
\hline Galvanized sheet surface & & & \\
\hline Gökçe chickpea & $1.01 \pm 0.01_{1}$ & $1.51 \pm 0.01_{\mathrm{f}}$ & $1.89 \pm 0.02_{\mathrm{c}}$ & $2.09 \pm 0.11_{\mathrm{a}}$ \\
Spanish chickpea & $1.13 \pm 0.01_{\mathrm{h}}$ & $1.74 \pm 0.03_{\mathrm{d}}$ & $1.98 \pm 0.02_{\mathrm{b}}$ & $2.14 \pm 0.04_{\mathrm{a}}$ \\
\hline Painted sheet surface & & & $1.59 \pm 0.02_{\mathrm{e}}$ & $1.89 \pm 0.02_{\mathrm{c}}$ \\
\hline Gökçe chickpea & $0.30 \pm 0.01_{\mathrm{k}}$ & $1.11 \pm 0.01_{\mathrm{h}}$ & $1.93 \pm 0.02_{\mathrm{bc}}$ \\
Spanish chickpea & $0.37 \pm 0.01_{\mathrm{k}}$ & $1.13 \pm 0.01_{\mathrm{h}}$ & $1.61 \pm 0.01_{\mathrm{e}}$ & $1.92 \pm 0.02_{\mathrm{bc}}$ \\
\hline Steel sheet surface & & & & $1.98 \pm 0.02_{\mathrm{b}}$ \\
\hline Gökçe chickpea & $0.66 \pm 0.04_{\mathrm{j}}$ & $1.40 \pm 0.01_{\mathrm{g}}$ & $1.79 \pm 0.01_{\mathrm{d}}$ & \\
Spanish chickpea & $0.98 \pm 0.00_{1}$ & $1.65 \pm 0.01_{\mathrm{e}}$ & $1.93 \pm 0.04_{\mathrm{bc}}$ & \\
\hline LSD=0.07221 & & & \\
\hline
\end{tabular}

When the averages of the angle values are evaluated, the flow rate value is determined as 0.74 $\mathrm{kg} \mathrm{s}^{-1}$ at the $24^{\circ}$ channel angle and as $1.99 \mathrm{~kg} \mathrm{~s}^{-1}$ at the $36^{\circ}$ channel angle $(\mathrm{F}=1968.13)$. The high slope angle caused an increase in the flow rate of the material and a decrease in the flow depth of the material. Elaskar et al. (2001) reported that the velocity of the sorghum grain and the maximum depth of steady flow show an approximately linear relationship with the slope of the channel.

According to the triple interaction results $(\mathrm{F}=2.27)$, the highest flow rate value was obtained on the galvanized sheet surface and the conveyor angle of $36^{\circ}$ in both chickpea varieties, and the lowest flow values were obtained at the conveyor angle of $24^{\circ}$ on the painted sheet surface.

\section{Conclusions}

Differences were found between the physical properties of the local population Spanish variety and the registered variety Gökçe chickpea seeds produced in the Konya region. In order for the flow to be smooth in both chickpea varieties, the channel angle must be higher than the static friction coefficient value of the grain on the relevant surface. This situation is especialy important on surfaces with high roughness values. As a result of the trials, we can state that the periodic cleaning of the channel surface has a positive effect on the flow rate. In this research, experimental observations are given regardless of a theory. In future studies, velocity profiles of the grain should be revealed and flow characteristics should be determined.

\section{References}

Akar R (2003). Konya'da yetiştirilen bamya çeşitlerinin bazı teknolojik özellikleri. Yüksek Lisans Tezi, Selçuk Üniversitesi Fen Bilimleri Enstitüsü, Tarım Makineleri Anabilim Dalı (Basılmamış), Konya.

Arıkaymak M, Hacıseferoğulları H. (2021). Physical Characteristics and Natural Flow Rates of Dry Bean Cultivars of a Local Population Grown In Konya Province of Turkey. Selcuk Journal of Agriculture and Food Sciences, 35(2), 131-135.

Baryeh EA (2001). Physical properties of bambara groundnuts. Journal of Food Engineering 47(4): 321-326.

Değirmencioğlu A, Tozan M, Caner OK, Güler H ve Bulancak S (1998). Farklı Kesit Alanı ve Orifislerden Serbest Akış Halindeki Gübre ve Tohumların Akışının Boyutsal Analiz Yoluyla Modellenmesi. 18. Ulusal Tarımsal Mekanizasyon Kongresi, 629-639, Tekirdağ.

Değirmencioğlu A, Güler H, Caner OK, Bulancak S, Tozan M (1999). Development of a Flow Rate Model of Grains and Fertilisers Through Circular and Sharp-Edged Orifices Using Dimensional Analysis. 7 th International Congress on Mechanization and Energy in Agriculture, 73-78, Adana. 
Elaskar SA, Godoy A, Mateo D, Seeber G (2001). PHPostharvest Technology: An Experimental Study of the Gravity Flow of Sorghum. Journal of Agricultural Engineering Research 79(1): 65-71.

Fitzpatrick JJ, Iqbal T, Delaney C, Twomey T, Keogh MK (2004). Effect of powder properties and storage conditions on the flowability of milk powders with different fat contents. Journal of food Engineering, 64(4), 435-444.

Gezer İ, Haciseferoğulları H, Demir F (2003). Some physical properties of Hacihaliloğlu apricot pit and its kernel. Journal of Food Engineering 56(1): 4957.

Gürhan R, Özarslan C, Topuz N, Akbaş T, Şimşek E (2009). Effects of moisture content on physical properties of black kabuli chickpea (Cicer arietinum L.) seed, Asian Journal of Chemistry, 21 (4), 3270-3278.

Gürsoy S, Güzel E (2010). Determination of physical properties of some agricultural grains, Research journal of applied sciences, engineering and technology, 2 (5), 492-498.

Iqbal A, Ateeq N, Khalil IA, Perveen S, Saleemullah S (2006). Physicochemical characteristics and amino acid profile of chickpea cultivars grown in Pakistan, Journal of Foodservice, 17 (2), 94-101.

Karacabey E, Güler H, Çoban T, Demir V (2009). Yamuk şekilli orifislerden serbest tohum ve gübre akışının genetik algoritma yöntemiyle optimizasyonu, Ege Üniversitesi Ziraat Fakültesi Dergisi, 46 (2), 129-136.
Karakullukçu E, Adak MS (2008). Bazı nohut (Cicer arietinum L.) çeşitlerinin tuza toleranslarının belirlenmesi, Journal of Agricultural Sciences, 14 (4), 313-319.

Kashaninejad M, Mortazavi A, Safekordi A, Tabil L G (2006). Some physical properties of Pistachio (Pistacia vera L.) nut and its kernel. Journal of Food Engineering, 72(1), 30-38.

Konak M, Çarman K, Aydın C (2002). PH-Postharvest Technology: Physical properties of chick pea seeds, Biosystems Engineering, 82 (1), 73-78.

Mohsenin NN (1986). Physical Properties of Plant and Animal Materials, second Edn. Gordon and Breach Science Publishers, New York.

Soliman SN, Yehia MO, Khatab AR, Zhran RA (2017). Flow Characteristics Of Rice Grains in Gravity Pipes. Misr Journal of Agricultural Engineering, 34(4), 2219-2232.

Turgut N, Kara M, Özsert İ, Öztürk İ (1994). Granüle Gübrelerin Değişik Orifislerden Akış Düzgünlüğü1, 15. Ulusal Tarımsal Mekanizasyon Kongresi, 20-22 Eylül 1994, Antalya.

Turgut N, Kara M, Özsert İ, Öztürk İ (1995). Granüle Gübrelerin Değişik Orifislerden Akış Düzgünlüğü2, Tarımsal Mekanizasyon 16.Kongresi, 5-6 Eylül 1995, Bursa.

TÜİK (2021). Türkiye İstatistik Kurumu Verileri [Erişim tarihi: 21.09.2021]. 